\title{
Penggunaan Media Film Dokumenter dalam Pembelajaran Menulis Puisi
}

\author{
Asep Firmansyah \\ asepfirmansyah776@gmail.com \\ STSI BCU Cirebon
}

\begin{abstract}
Abstrak. Menulis merupakan kegiatan yang tidak hanya menjadikan seseorang semakin cerdas, tetapi juga akan mencerdaskan orang lain. Walaupun demikian, kegiatan menulis belum banyak dilakukan oleh siswa. Hasil observasi awal di beberapa SMP Cirebon Timur, diperoleh data bahwa siswa memiliki kemampuan yang rendah dalam menulis, khususnya menulis puisi. Mereka kesulitan menuangkan imajinasinya dan kesulitan memilih kata-kata pada saat menulis puisi. Berdasarkan data tersebut, maka diperlukan cara yang lebih menarik dalam pembelajaran menulis puisi, salah satu solusinya yaitu menggunakan media film dokumenter. Penggunaan Media film dokumenter dalam pembelajaran puisi tersebut penuis jadikan sebagai bahan penelitian. Metode yang digunakan dalam penelitian ini yaitu metode eksperimen (quasi), dengan nonequivalent control group design. Adapun teknik pengumpulan data yang dilakukan yaitu tes dan nontes (observasi). Setelah melakukan penelitian hasil yang diperoleh yakni, hasil tes siswa kelas eksperimen lebih baik daripada kelas kontrol. Kelas eksperimen yang menggunakan media film dokumenter memeroleh skor rata-rata 78,17 sedangkan kelas kontrol yang menggunakan media gambar memeroleh skor rata-rata 67,97. Hasil perhitungan uji t juga membuktikan bahwa $t_{\text {hitung }}>t_{\text {tabel }}$ atau 2,50 $>1,99$ pada taraf signifikan 5\%. Hal ini, berarti $\mathrm{H}_{0}$ ditolak dan $\mathrm{H}_{1}$ diterima yang berarti penggunaan media film dokumenter dalam pembelajaran menuis puisi efektif. Selain itu, hasil observasi juga menunjukkan bahwa penggunaan media film dokumenter dapat meningkatkan aktivitas siswa dan guru.
\end{abstract}

Kata Kunci: film dokumenter, menulis puisi, pembelajaran

\section{Pendahuluan}

Menulis merupakan keterampilan berbahasa yang tidak banyak orang melakukannya. Hal ini karena keterampilan menulis tidak mudah dilakukan. Nurgiyantoro (2011) menyatakan bahwa dibandingkan tiga kompetensi berbahasa yang lain, kompetensi menulis secara umum boleh dikatakan lebih sulit dikuasai bahkan oleh penutur asli bahasa yang bersangkutan sekalipun. Dari pernyataan tersebut dapat diketahui bahwa keterampilan menulis memiliki tingkat kesukaran yang lebih tinggi dibandingkan keterampilan berbahasa yang lain. Maka dari itu perlu latihan dan kebiasaan agar keterampilan menulis tersebut dapat dikuasai. Bahkan lebih jauh dari itu keterampilan menulis harus ditanamkan sejak dini, yakni sejak mulai masuk sekolah agar kemampuannya dalam menulis dapat meningkat seiring meningkatnya usia dan tahapan pendidikannya.

Rosidi (2009) mengungkapkan bahwa kegiatan menulis sangat penting dalam pendidikan karena dapat membantu siswa berlatih berpikir, mengungkapkan gagasan, dan memecahkan masalah. Demikian juga menurut Harefa (2010) bahwa "Menulis itu sudah jelas merupakan salah satu cara meningkatkan kecerdasan." Dari pendapat tersebut, dapat disimpulkan bahwa menulis dapat menjadikan peserta didik semakin cerdas dan kreatif dalam berpikir.

Penulis mendapat informasi dari guru bahasa Indonesia SMP di beberapa sekolah Cirebon Timur, bahwa siswa memiliki kemampuan yang rendah dalam kegiatan menulis khususnya menulis puisi. Mereka kesulitan menuangkan imajinasinya dalam bentuk puisi, seperti mengembangkan kata-katanya, menuliskan kata berkonotasi, bahkan ada siswa yang 
tidak dapat berimajinasi; mereka mengeluh tidak mempunyai ide dan tidak tahu apa yang akan mereka tulis dalam puisinya.

Berdasarkan hal tersebut, penulis mengidentifikasi permasalahan yang terjadi pada pembelajaran menulis puisi di beberapa SMP wilayah Cirebon Timur, yaitu sebagai berikut.

1) Siswa memiliki kemampuan yang rendah dalam menulis puisi.

2) Pengetahuan siswa tentang menulis puisi minim sehingga mereka kesulitan dalam menulis puisi.

3) Siswa memiliki daya imajinasi yang rendah.

4) Cara dan strategi belajar belum tepat sehingga kurang memberikan pengaruh positif pada peningkatan hasil dan motivasi belajar siswa.

Berkaitan mengenai pentingnya menulis puisi. Menurut Pradopo (2012), "Puisi itu merupakan rekaman dan interpretasi pengalaman manusia yang penting, digubah dalam wujud yang paling berkesan”. Dengan kreatif menulis puisi diharapkan siswa akan peka dan empati terhadap lingkungan hidupnya, kemudian siswa akan bertindak yang terbaik dalam kehidupannya. Seperti dikatakan Siswanto (2008) bahwa melalui sastra (termasuk puisi) kita bisa mengembangkan peserta didik dalam hal keseimbangan antara spiritual, emosional, etika, logika, estetika, dan kinestetika; mengembangkan kecakapan hidup; belajar sepanjang hayat; serta pendidikan kemenyeluruhan dan kemitraan. Oleh karena itu, siswa harus benar-benar memahami pembelajaran menulis puisi untuk diaplikasikan dalam hidupnya sehari-hari.

Untuk mencapai keberhasilan siswa dalam menulis puisi, maka diperlukanlah suatu strategi, metode, ataupun media yang tepat dalam membelajarakannya. Dalam penelitian ini, penulis menggunakan media film dokumenter sebagai suatu strategi dalam membelajarkan siswa menulis puisi. Menurut Pratista (2008), film dokumenter adalah penyajian fakta yang berhubungan dengan manusia, tokoh, peristiwa, dan lokasi yang nyata. Dari karakteristik tersebut, penggunaan media film dokumenter ini diharapkan mampu merangsang imajinasi siswa dalam menulis puisi, sehingga mereka tidak lagi merasa kesulitan dan kebingungan dalam menulis puisi. Melalui media film dokumenter ini, siswa diharapkan mampu menuangkan ide atau imajinasinya ke dalam bentuk puisi.

Adapun melalui penelitian ini, penulis ingin mengetahui (1) apakah penggunaan media film dokumenter dalam pembelajaran menulis puisi pada siswa kelas VIII SMP Negeri 1 Ciledug efektif? (2) bagaimana aktivitas guru dan siswa kelas VIII SMP Negeri 1 Ciledug dalam pembelajaran menulis puisi dengan menggunakan media film dokumenter?

Terkait dengan pembahasan di atas, peneliti akan melakukan penelitian mengenai hal tersebut dengan judul penelitian Penggunaan Media Film Dokumenter dalam Pembelajaran Menulis Puisi pada Siswa Kelas VIII SMPN 1 Ciledug.

\section{Metode}

Metode yang digunakan peneliti dalam penelitian ini, yaitu metode eksperimen. Penelitian eksperimen merupakan penelitian yang dimaksudkan untuk mengetahui ada tidaknya akibat dari objek sasaran yang dikenakan perlakuan. Hal ini seperti yang disampaikan Sugiyono (2011) bahwa penelitian eksperimen yaitu penelitian yang digunakan untuk mencari pengaruh dari perlakuan tertentu. Dalam penelitian ini, metode eksperimen yang digunakan oleh peneliti yakni eksperimen semu (quasi experiment). Desain penelitian yang digunakan penulis dalam 
melakukan penelitian ini adalah nonequivalent control group design. Dalam nonequivalent control group design ini dua kelompok dipilih dengan cara teknik sampling purposive. Adapun teknik pengumpulan data yang digunakan dalam penelitian ini, yakni berupa tes dan nontes (observasi).

\section{Hasil dan Pembahasan}

\section{Keefektifan Media Film Dokumenter dalam Pembelajaran Menulis Puisi}

Pada pembelajaran menulis puisi hasil belajar siswa diukur dengan menggunakan instrumen tes tulis, yakni untuk mengetahui keefektifan penggunaan media film dokumenter dalam pembelajaran menulis puisi. Berdasarkan hasil tes pembelajaran menulis puisi dapat dilihat perbedaan secara signifikan terhadap kemampuan menulis puisi. Nilai rata-rata saat tes awal dan tes akhir pembelajaran menulis puisi di kelas eksperimen lebih baik dibandingkan dengan kelas kontrol. Pernyataan hasil tes siswa tersebut dapat dilihat dari rincian berikut. Hasil tes awal pada kelas eksperimen yang mendapat nilai tidak memenuhi syarat KKM sebanyak 31 orang $(88,57 \%)$ dan yang sudah mencapai syarat KKM berjumlah 4 orang $(11,42 \%)$, hasil tes akhir yang sudah mencapai syarat KKM berjumlah 20 orang $(57,14 \%)$ dan yang tidak memenuhi syarat KKM berjumlah 15 orang (42,85\%), adapun hasil rata-rata tes awal sebesar 52,34 dan tes akhir sebesar 78,17. Dari pernyataan tersebut, terdapat peningkatan hasil belajar siswa setelah diterapkannya media film dokumenter dalam pembelajaran menulis puisi pada kelas eksperimen. Sementara itu, hasil tes awal pada kelas kontrol menunjukkan siswa yang belum memenuhi syarat KKM berjumlah 33 siswa $(94,28 \%)$ dan yang tuntas berjumlah 2 siswa $(5,71 \%)$. Sedangkan pada hasil tes akhir yang mendapat nilai tuntas sebanyak 14 siswa (40\%) dan yang tidak tuntas sebanyak 21 siswa (60\%). Hasil rata-rata tes awal kelas kontrol sebesar 51,4 dan hasil rata-rata tes akhir kelas kontrol sebesar 67,97.

Dari pernyataan di atas, dapat disimpulkan bahwa hasil tes siswa kelas eksperimen lebih baik daripada kelas kontrol. Hal ini terbukti dari nilai rata-rata tes akhir kedua kelas tersebut. Kelas VIII E sebagai kelas eksperimen yang menggunakan media film dokumenter pada pembelajaran menulis puisi memeroleh skor nilai rata-rata sebesar 78,17 sedangkan kelas VIII D sebagai kelas kontrol yang menggunakan media gambar pada pembelajaran menulis puisi memeroleh skor nilai rata-rata sebesar 67,97. Hal tersebut disebabkan karena penggunaan media film dokumenter dalam pembelajaran menulis puisi lebih merangsang siswa dalam menemukan ide kreatifnya dan lebih bebas dalam mengembangkan daya khayal atau imajinasinya. Selain itu, hasil perhitungan uji $\mathrm{t}$ juga membuktikan bahwa $t_{\text {hitung }}>\mathrm{t}_{\text {tabel }}$ atau 2,50 $>1,99$ pada taraf signifikan 5\%. Hal ini, berarti $\mathrm{H}_{0}$ ditolak dan $\mathrm{H}_{1}$ diterima.

\section{Aktivitas Siswa dan Guru dalam Pembelajaran Menulis Puisi dengan Menggunakan Media Film Dokumenter}

Dalam penilaian proses pembelajaran, penulis menggunakan instrumen observasi dengan tujuan untuk mengetahui aktivitas siswa dan guru dalam kegiatan belajar mengajar berlangsung. Berdasarkan hasil pengamatan yang penulis lakukan bahwa aktivitas pembelajaran yang dilakukan siswa di kelas eksperimen sudah baik, karena siswa dapat mengikuti kegiatankegiatan yang diberikan guru. Hal ini dibuktikan dengan pemerolehan persentase dari keaktifan siswa sebagai berikut. Dua puluh tujuh siswa $(77,14 \%)$ menanggapi secara antusias ketika guru 
melakukan apersepsi pada kegiatan awal sedangkan 8 siswa lainnya hanya memerhatikan temantemannya yang lain. Tiga puluh siswa $(85,71 \%)$ aktif menyimak dan berperan sebagai subjek pembelajaran saat mempelajari materi menulis puisi sedangkan 5 siswa lainnya pasif. Dua puluh delapan siswa (80\%) turut serta menganalisis unsur-unsur puisi dari contoh puisi bersama guru sedangkan 7 siswa lainnya hanya diam. Tiga puluh tiga siswa $(94,28 \%)$ menonton tayangan film dokumenter dengan sungguh-sungguh sedangkan 2 siswa lain tidak terlalu fokus menonton tayangan film tersebut. Dua puluh satu siswa (60\%) memberikan tanggapan dari tayangan film dokumenter tersebut sedangkan 12 siswa lain mendengarkan dan 2 siswa lain tidak memperhatikan. Tiga puluh lima siswa (100\%) mengerjakan tugas menulis puisi yang diberikan oleh guru; seluruh siswa mengerjakan tugas menulis puisinya setelah menonton tayangan film dokumenter tersebut. Tiga puluh dua siswa $(91,42 \%)$ aktif memberikan tanggapan mengenai unsur-unsur puisi dari hasil kreatif salah satu siswa yang dituliskan di papan tulis sedangkan 3 siswa lain hanya diam. Dua puluh lima siswa $(71,42 \%)$ melakukan konfirmasi baik dalam bentuk tanggapan maupun pertanyaan selama proses pembelajaran menulis puisi.

Data observasi guru menggambarkan bahwa kemampuan guru dalam mengajar sudah baik. Hal ini ditunjukkan dalam beberapa aspek yaitu menyampaikan kompetesi dasar dan tujuan pembelajaran menulis puisi dengan media film dokumenter jelas dan komunikatif. Sebelum melakukan psoses pembelajaran, guru menggali kompetensi siswa untuk mengetahui kemampuan awal atau skemata siswa dalam menulis puisi. Dalam menyampaikan materi ajar, guru melakukan kegiatan pembelajaran dengan melibatkan siswa sebagai pembelajar. Pada saat guru akan menayangkan film dokumenter, guru memberikan arahan tentang sikap yang harus dilakukan siswa. Setelah siswa menonton film dokumenter, guru memberikan tugas menulis puisi dengan ekspresi dan bahasa yang bersahabat. Selanjutnya, guru mengajak siswa untuk menganalisis unsur-unsur puisi yang ditulis di papan tulis dari hasil proses kreatif siswa setelah menonton film dokumenter. Dalam pembelajaran tersebut, hubungan guru dan siswa dalam proses pembelajaran berlangsung komunikatif. Pada akhir pembelajaran, guru dan siswa melakukan diskusi tentang materi yang telah dipelajarinya.

Berdasarkan hasil observasi di atas, dapat ditarik kesimpulan bahwa pembelajaran menulis puisi dengan menggunakan media film dokumenter di kelas eksperimen dapat meningkatkan aktivitas siswa dan guru.

\section{Simpulan}

Berdasarkan analisis data dengan menggunakan uji statistik ( $t$-tes) diperoleh simpulan bahwa penggunaan media film dokumenter dalam pembelajaran menulis puisi pada siswa kelas VIII SMP Negeri 1 Ciledug efektif. Hal ini terbukti dari hasil uji statistik ( $t$-tes) didapat nilai $t_{\text {hitung }}$ adalah 2,50 sedangkan $t_{\text {tabel }}$ 1,99 pada taraf kepercayaan 5\%. Hal ini membuktikan bahwa $t_{\text {hitung }}>t_{\text {tabel. }}$

Hasil pembelajaran siswa pada kelas VIII E yaitu kelas eksperimen yang terdiri dari 35 sampel penelitian, diperoleh skor nilai 2736 dengan rata-rata 78,17. Hasil tes akhir tersebut menunjukkan adanya peningkatan nilai yang dihasilkan oleh siswa. Pembelajaran menulis puisi dengan menggunakan media film dokumenter ini memberikan pengaruh positif pada diri siswa sehingga berdampak pada meningkatknya daya imajinasi dan kreativitas untuk menulis puisi.

Hasil observasi pada proses pembelajaran berdasarkan pedoman observasi menunjukkan 
bahwa penggunaan media film dokumenter dalam pembelajaran menulis puisi pada siswa kelas VIII SMP Negeri 1 Ciledug mampu meningkatkan aktivitas belajar siswa. Hal ini terbukti dari hasil deskripsi lembar pedoman observasi menunjukkan peningkatan aktivitas belajar siswa. Dari pernyataan tersebut, dapat disimpulkan bahwa penggunaan media film dokumenter dalam pembelajaran menulis puisi pada siswa kelas VIII SMP Negeri 1 Ciledug mampu meningkatkan aktivitas belajar siswa.

Penggunaan media film dokumenter dalam proses pembelajaran menulis puisi dapat meningkatkan minat belajar siswa, merangsang siswa berimajinasi lebih bebas lagi, memotivasi siswa agar terus belajar, dan menghilangkan rasa bosan dalam pembelajaran. Sementara itu, bagi guru, media pembelajaran tersebut sangatlah bermanfaat sebagai penunjang dalam mengefektifkan proses pembelajaran agar mencapai tujuan pembelajaran yang lebih baik.

\section{Daftar Pustaka}

Aminuddin. (2011). Pengantar Apresiasi Karya Sastra. Bandung: Sinar Baru Algesindo. Arikunto, S. (2010). Manajemen Penelitian. Jakarta: Rineka Cipta.

\section{(2006). Prosedur Penelitian Suatu Pendekatan Praktik. Jakarta: Riene}

Arsyad, A. (2011). Media Pembelajaran. Jakarta: Raja Grafindo Persada.

Ayawaila, G. R. (2007). Dokumenter; dari Ide Sampai Produksi. Jakarta: FFTV-IKJ Press.

Baskoro, E. P. (2008). Media Pembelajaran. Cirebon: Swagati Press.

De Porter, B. dan Mike H. (2007). Quantum Learning. Bandung: Kaifa.

Djaali. (2007). Psikologi Pendidikan. Jakarta: PT Bumi Aksara.

Djamarah, S. B. dan Aswan Z. (2006). Strategi Belajar Mengajar. Jakarta: PT Rineka Cipta.

Effendy, H. (2009). Mari Membuat Film. Jakarta: Erlangga.

Fakhruddin, A. U. (2010). Menjadi Guru Favorit. Jogjakarta: Diva Press.

Harefa, A. (2010). Happy Writing. Jakarta: PT Gramedia Pustaka Utama.

Hidayah, A. (2012). Membaca Super Cepat. Jakarta: Laskar Aksara.

Hidayati, L. (2012). Menumbuhkan Karakter Positif dengan Menulis Puisi. Yogyakarta: Fire Publisher.

Hutabarat, A. P. (2010). Menanam Benih Kata tentang Menulis Puisi. Lampung: Dewan Kesenian Lampung.

Jabrohim, dkk. (2009). Cara Menulis Kreatif. Yogyakarta: Pustaka Pelajar.

Javandalasta, P. (2011). 5 Hari Mahir Bikin Film. Surabaya: Mumtaz Media.

Komaidi, D. (2011). Panduan lengkap Menulis Kreatif. Yogyakarta: Sabda Media.

Majid, A. (2011). Perencanaan Pembelajaran. Bandung: PT Remaja Rosdakarya.

Maulana, S. F. (2012). Apresiasi \& Proses Kreatif Menulis Puisi. Bandung:

Nuansa.

Munadi, Y. (2013). Media Pembelajaran; Sebuah Pendekatan Baru. Jakarta: GP Press Group.

Muslich, M. (2007). KTSP Dasar Pemahaman dan Pengembangan. Jakarta: Sinar Grafika Offset.

Nurgiyantoro, B. (2010). Penilaian Pembelajaran Bahasa. Yogyakrta: BPFE-Yogyakarta. Pradopo, R. D. (2012). Pengkajian Puisi. Yogyakarta: Gadjah Mada University Press. 
Pratista, H. (2008). Memahami Film. Yogyakarta: Homerian Pustaka.

Raharja, R. (2012). Menulis Super Cepat. Jakarta: Laskar Aksara.

Rosidi, I. (2009). Menulis Siapa Takut? Panduan bagi Penulis Pemula. Yogyakarta: Kanisuis.

Rozak, A. (2011). Menulis Skripsi Itu Tidak Sulit. Cirebon: Unswagati Cirebon.

Rusyana, Y. (1982). Metode Pengajaran Sastra. Bandung: Gunung Larang.

Sadiman, A S. dkk. (2009). Media Pendidikan: Pengertian, Pengembangan, dan Pemanfaatannya. Jakarta: Raja Grafindo Persada.

Semi, M. A. (2007). Dasar-Dasar Keterampilan Menulis. Bandung: Angkasa

Siswanto, W. (2008). Pengantar Teori Sastra. Jakarta: PT Grasindo.

Subana, M. dan Sunarti. (2011). Strategi Belajar Mengajar Bahasa Indonesia. Bandung: Pustaka Setia.

Sudjana, N. (2010). Dasar-Dasar Proses Belajar Mengajar. Bandung: Sinar Baru Algensindo. Rosdakarya.

Sudjana, N. dan Ahmad R. (2010). Media Pengajaran. Bandung: Sinar Baru Algensindo.

Sukmadinata, N. S. (2012). Metode Penelitian Pendidikan. Bandung: Remaja Rosdakarya.

Sugiyono. (2011). Metode Penelitian Pendidikan. Bandung: Alfabeta.

Sukino. (2010). Menulis itu Mudah. Yogyakarta: Pustaka Populer.

Waluyo, H. J. (1995). Teori dan Apresiasi Puisi. Surakarta: Erlangga.

---... (2003). Apresiasi Puisi. Jakarta: Gramedia Pustaka Utama.

Zulkifli. (2005). Psikologi Perkembangan. Bandung: PT Remaja Rosdakarya 
